\title{
SEMANTIC FEATURES OF IDIOMS (ON THE EXAMPLE OF THE WORKS OF MURAD MUHAMMAD DUST)
}

\section{Dr. Abdumalik K. Khamidov}

Associate Professor, Doctor Of Philosophy (Phd) Department Of Uzbek Language And Literature Of The Denau Institute Of Pedagogy And Enterpreneuship Uzbekistan

\section{ABSTRACT}

This article discusses semantic features of idioms (On the example of the works of Murad Muhammad Dust). Idioms are figurative language tools that arise as a product of human thinking. It can be noted that idioms are interpreted in sources as a manifestation of phraseological units. In particular, the French linguist Sh. Bally considers idioms as phraseological units formed on the basis of the addition of words that have lost their semantic meaning, while O.S. Akhmanova interprets them as linguistic units. Explanatory dictionaries of Uzbek linguistic terms also provide similar explanations for idioms.

KEYWORDS: - Idiom, idiomatic connection, phraseological unit, semantic, functional, linguistic term, individual, speech unit, artistic speech, figurative meaning, lexical meaning.

\section{INTRODUCTION}

Idioms are figurative language tools that arise as a product of human thinking. It can be noted that idioms are interpreted in sources as a manifestation of phraseological units. In particular, the French linguist Sh. Bally considers idioms as phraseological units formed on the basis of the addition of words that have lost their semantic meaning, while O.S. Akhmanova interprets them as linguistic units. Explanatory dictionaries of Uzbek linguistic terms also provide similar explanations for idioms.

Idiom (Greek specific expression, phrase). Expression of an idea, event, event, the form of which does not correspond to logic. They are unique to a particular language and cannot be literally translated into other languages.

\section{THE MAIN RESULTS AND FINDINGS}

Although idioms and phrases are considered in the sources as linguistic units formed on the basis of expressive meaning, their differences are reflected in the explanatory dictionaries of linguistic terms. Although the meaning of idioms seems to have changed, in fact, idioms are not words with a figurative meaning, but lexical units that are formed based on the expression of certain content by the 
CURRENT RESEARCH JOURNAL OF PHILOLOGICAL SCIENCES 2(12):

79-83, December 2021

DOI: https://doi.org/10.37547/philological-crjps-02-12-17

ISSN 2767-3758

(C)2021 Master Journals

Crossref do

gil Google

Accepted09th December, 2021 \& Published 14 ${ }^{\text {th }}$ December, 2021

owner of the language in a new form. Reflecting on the various features of idioms and phraseological units, A. Yuldashev writes: "The difference between IQ and phraseological units is not only structural, but also semantic-functional, methodological. The lexical meaning of IQS is expressed directly, and not through an image, and in phraseological units, reality is expressed through a figurative meaning. The figurative meaning in phraseological units is based on the nominative case of the components. Both idioms and phrases are units that express a meaning that is different from the original meaning of a word, which is formed on the basis of word addition, word formation. In this case, Sh. Rakhmatullaev shows that the phrase is a composite linguistic unit, but its meaning is not equal to the meaning expressed by words in the composition. This compatibility in terms of education and expression means that idioms and phrases are linguistic units that are close to each other in form and content. Idioms are the means by which the language skills of the speaker are used, mainly in artistic speech, partly in oral speech, and they differ from other language tools mainly in their specificity of individual use.

The source of idioms in the Uzbek language is oral and artistic speech, and it is believed that a number of idioms found in literary texts are present in oral speech, in ordinary speech. The features of such units form the basis for their introduction into literary texts. For example, Izbosarov zo'r yigit, dedi. - Tutgan joyini qo'ymaydi("Iste'fo") - The meaning of the phrase tutgan joyini qo'ymaydi in the phrase is formed on the basis of the lexical meaning of the words included in the composition. Since this idiom is bajaraman degan ishini bajaradi, aytganini qiladi, it is completely separated from the meaning of the words in it, the meanings are expressed, and this meaning has an implicit expression in relation to the text in this idiom. Or if the idiom Mening og'zim kuyganroq, shirin so'zga ishonishim qiyin ("Iste'fo") , og'zim kuygan, means oppression in this text, in another text the phrase "burning in the mouth" can be used correctly, but not as an idiom, because when it is expressed like a burning sensation in the mouth during consumption, this expression corresponds to the total value of the components of the compound. The fact that the meanings "burning mouth" and "suffering" are expressed through the combination of a burnt mouth indicates that it also exists in speech in the form of a phrase and an idiomatic union. The emergence of the idiom is associated with the need for a figurative and artistically expressive expression of thought. This is because an idiom calls an event without an original term, an action-state, based on an understanding of similar aspects of another thing-event, a state-action. The descriptive features of such linguistic units are stronger than other words. As a result, the idea expressed with the help of these means can acquire an artistic impression. For example, the word jilovlab combined with an idiom, Elomonov xayolini jilovlab, nonushtaga band bo'ldi ("Iste'fo") is not imaginary. The emergence of this idiom is associated with the figurative expression of thought and is based on imaginary concepts. To create an idiom, the limitlessness of human imagination, the breadth of which is compared to the movement of a galloping horse. To stop the horse, the runner must be restrained. In fact, idioms are actually vague, their meaning is determined only in relation to other things, for example, a combination of idioms does not express a clear meaning, its meaning is realized in a state of comparison. This shows that idioms are unique as important linguistic units that are not visible from the surface. Therefore, the meaning expressed by the idiom is broader than the meaning expressed in the usual case. Because the meanings of idioms are not the initial lexical meaning, but a hidden meaning, that is, a new meaning expressed on the basis of the creator's figurative thinking, with the aim of organizing the 
CURRENT RESEARCH JOURNAL OF PHILOLOGICAL SCIENCES 2(12):

79-83, December 2021

DOI: https://doi.org/10.37547/philological-crjps-02-12-17

ISSN 2767-3758

(C)2021 Master Journals

Crossref dof 81 Google

Accepted09th December, 2021 \& Published $14^{\text {th }}$ December, 2021

artistic impact of the work. The formation of a certain meaning using idioms is an absolutely relative phenomenon, depending on the creator's ability to perceive the world, his language skills in defining and describing the world. Idioms, as distinctive linguistic units in terms of education and expression, can also acquire important features in the speech process. The creation of idioms and their frequent use in artistic discourse is due to the fact that they can express subtle meaning and are a new means of expression.

The writer Murad Muhammad Dost is an artist who, like other lexical units, purposefully uses idioms. The idioms found in the writer's work can be divided into traditional and individual ones. Traditional idioms are well-known units that exist in speech, determined by the presence of imagery in the semantics of their use in speech. For example, idioms such as qovog'ini solmoq, qovog'ini uymoq, qil sig'may (ko'ngliga) are actively used in oral speech to describe a person's sadness. In the works of the author, there are also cases when these expressions are used to express various situations and have an elusive meaning. Usually, qovog'ini solmoq, qovog'ini uymoq is the expression on the face of a person who is upset about something, units formed in comparison with cases of drooping of the eyelid. Accordingly, these lexical elements represent a situation when a person is in distress. This situation can also be expressed in the words xafa, juda xafa (sad, very sad) in the language, but it does not depict a person, his signs of sadness do not appear in the eyes of a person. In this respect, the verbal features of these idioms are manifested. Apparently, the creation of these idioms is directly related to the comparison of things, the description on this basis, the artistic painting of thought as a result of the description. In addition, in idiom semantics, meaning sometimes exists in a latent state. In the works of Murad Muhammad Dust, these idioms are used not in the sense of sadness from grief, but in the sense of getting into this situation O'qiganman, - dedi Yaxshiboev battar qovog'ini solib, so'ng mahmadonaga tanbeh berdi. -0'shani o'qimasdan ham yozsa bo'ladi ("Lolazor") - in a sentence with the idiom qovog'ini solmoq to express dissatisfaction with the words of the interlocutor. At this stage, there is no feeling of resentment, but there is a state of dissatisfaction with the opinion of the interlocutor. Or - Yo'q, xuddi shunaqaman, - dedi G'aybarov qovog'ini solib ("Galatepaga qaytish") and this idiom was used to show his natural darkness, the heaviness of his character. Yaxshiboev ham qovog'ini uydi, boshini egdi, go'yo cheksiz g'amga giriftor bo'lganday ("Lolazor") and the idiom qovog'ini uydi was used to express his sadness. The idiom ko'ngliga qil sig'maydi is also used to describe this state of mind of a person. This lexical unit is also widely used in traditionally used oral speech and literary texts. In terms of expression, it is equivalent to the lexical means mentioned above, i.e. expresses extreme sadness. For example Garchi, ko'ngliga qil sig'may yurgan esa-da, shu gapni eshitib, Elomonov kulib yubordi ("Iste'fo"). qovog'i osilmoq, qovog'ini uymoq, ko'ngliga qil sig'may, which are synonymous with the expression "sadness," confirm the fact that idioms also have a semantic feature. Many idioms in the author's works, such as yuzga oyoq qo'ymoq, gap qochmoq, boshi ketmoq, ammamning buzog'i, ensasi qotmoq, ko'zi tushmoq, taxta bo'lmoq, ko'zga chalinmoq, og'zi yomon, tili uzun, qo'li kalta, ko'zi o'tkir, provide certain meanings in a non-traditional way of artistic sensitivity. The fact that these idioms are syntactically and structurally incompatible with ordinary compounds, that one of the words in the composition does not express the original meaning, is the basis for the expression of artistic thought. For example, words in the idiom taxta bo'lmoq do not mean anything in the text, based on their original meaning. 
CURRENT RESEARCH JOURNAL OF PHILOLOGICAL SCIENCES 2(12):

79-83, December 2021

DOI: https://doi.org/10.37547/philological-crjps-02-12-17

ISSN 2767-3758

(C)2021 Master Journals

Crossref do

gil Google

Accepted09th December, 2021 \& Published 14 ${ }^{\text {th }}$ December, 2021

In the sense of an idiom, it is important to compare the situation with something else, with the situation. Binafshaxon neki baloni kutgan bo'lsa kutgan, lekin bunaqasini o'ylamagan ekan, taxta bo'lib qoldi ("Iste'fo"). The idiom qotib qoldi is also used to express this meaning, and the comparison of an unchanging, stable state of a person at a given moment with an object and another state has led to the formation of idioms.

Idioms are new words that are completely different from the words they contain, even if they consist of a combination of two or more words that already exist in the language. For example, when the combination Qo'li kalta is used in relation to the original meaning of the words in that conjunction, it represents the meaning of poverty. The fact that the idiom is not used in the same sense, but in the sense of "impossible", shows that this is another lexical unit that has a formal connection with a short combination of hands which means size. The creation of a particular lexical unit in a language is based on the general grammatical features of the language. At the same time, special attention is paid to the human consciousness of the lexical environment, the process of expressing meaning in the imagination. Undoubtedly, the creation of many lexical means is based on a figurative perception of the world, an effective presentation of messages about things to people. Idioms are such linguistic units that indicate that they are created on the basis of the wisdom of people, the wealth of the world of thinking of people. The writer Murad Muhammad Dust is a creator who skillfully used such examples of folk wisdom in his works and managed to create new idioms. In the writer's works, there are many idioms that are the product of folk tradition, are used on the basis of individual skill and can acquire a linguo-poetic essence with the ability to express subtle meaning. For example, O'g'il Raim oqsoqolning o'g'li edi, yotig'i bilan, lekin rostini aytdi: endi, ota qiz bolaning tuprog'i bo'shroq keladi-da ("Galatepaga qaytish"). In the component of the idiom tuprog'i bo'sh, which is used in relation to a person, there is a word that, in terms of meaning, serves to express the characteristics of a person. For example, the presence of semantics for interpreting human character in the sense of bo'sh could be the basis for the formation of this idiom. There is no doubt that such idioms that do not fit the pattern of literary conjugation in the original sense of the words in this compound word, which seem difficult to ascribe to a person in terms of form, are means of providing emotionality in terms of expression. An important word that determines the meaning of the idiom is the word bo'sh. Under this word, signs of a female character are gentleness, female kindness, confidence, not always a feeling of the need to think independently when making decisions. The lexical unit representing this concept does not exist in the language. Accordingly, the idiom stupid bo'sh attracts attention as an important lexical unit expressing this concept. The function of many idioms in the speech system is determined by the nature of the expression, since idioms are often a means of expressing concepts that are not expressed in language. It is known that the use of linguistic units in the sense of naming is universal, as a result of the choice of forms expressing different meanings in literary texts, the language becomes lexically enriched, the main part of such means differs in speech specifics and creates various methodological possibilities. Therefore, lexical units of this type are considered speech, and their main function is determined by their specificity for speech. Idioms are also such speech units that create different speech possibilities, motivate their creation. For example, kulgisini yig'ishtirmoq (Lekin xona burchagida, servant yonida, yumushini tugatib, endi nima qilarini bilmay garangsib turgan Ko'klamovga ko'zi tushdi-yu, kulgisini yig'ishtirdi. "Lolazor") from the point of view of the language) is an unusual expression. Since the word yig'ishtirmoq has no 
CURRENT RESEARCH JOURNAL OF PHILOLOGICAL SCIENCES 2(12):

79-83, December 2021

DOI: https://doi.org/10.37547/philological-crjps-02-12-17

ISSN 2767-3758

(C)2021 Master Journals

Crossref do

8 Google

Accepted09th December, 2021 \& Published $14^{\text {th }}$ December, 2021

meaning with the word kulgisini yig'ishtirmoq means meaning in accordance with linguistic norms when used with certain object names: for example uyni yig'ishtirmoq, narsalarini yig'ishtirmoq (tidying up the house, cleaning things). Accordingly, the word yig'ishtirmoq (in the compound kulgisini yig'ishtirmoq was associated with the word kulgi away from the lexical meaning and meant to show oneself upset. This shows that this lexical tool has a new meaning. This is an indicator that idioms are a means of creating new meaning in the process of speech. The expression of new meanings through the formation of idioms is associated with the perception of the creator, understanding of the world, the search for lexical means that correspond to the expression in the expression of what is understood. The expression of kulgisini yig'ishtirmoq is typical for the individual style of the writer and could logically express the meaning corresponding to this text.

It seems that idioms not only express meaning, but also emerge as a means of observing human phenomena, their actions, unknown to others, drawing conclusions from observations and their description.

\section{Conclusion}

In conclusion, it should be noted that in the works of Murad Muhammad Dust, like all linguistic means, idioms are used in accordance with their intended purpose, which shows that lexical units play an important role in the speech process.

\section{5.}

3. Mahkamov N. Irmatov I. Explanatory dictionary of linguistic terms. - Tashkent: Fan, 2013. - P.47.

4. Yuldashev A. Linguocognitive study of idiomatic conjunctions. - Toshkent, 2016. - Б. 42 - 186.

5. Rahmatullaev Sh. Annotated phraseological dictionary of the Uzbek language. - Tashkent: Teacher, 1978. - B. 4.

6. Murod Muhammad Dost. "Resignation." Tashkent, 1989.

7. Murod Muhammad Dost. "Lolazor". Tashkent: Uzbekistan, 2016.

8. Murod Muhammad Dost. "Return to Galatepa or the story of the happy Gaybarov". Tashkent: G'afur Gulom, 2009.

\section{REFERENCES}

1. Balli S. French stylistics. - $\mathrm{M}$.: Foreign literature, 1961. - P. 344.

2. Akhmanova O.S. Dictionary of linguistic terms. - M .: Soviet encyclopedia, 1966. - S. 